\title{
EFEK FERMENTASI Trichoderma sp. TERHADAP KADAR PROTEIN, TANNIN, SELULOSA PADA HIJAUAN POTENSI ANTELMINTIK
}

\author{
Pramu $^{1}$, Kusuma,Y.R. ${ }^{2}$, Susilo, T. $^{3}$ \\ $\left.{ }^{123}\right)$ Staf Pengajar STPP Magelang \\ email: pramucinagara@yahoo.com
}

\begin{abstract}
ABSTRAK
Upaya peningkatan produktivitas ternak ruminansia biasanya berhubungan dengan dua hal yaitu: nutrisi dan kesehatan. Penelitian mengenai fermentasi pakan menggunakan mikroorganisme pada umumnya bertujuan untuk meningkatkan nilai nutrisi, memanfaatkan melimpahnya limbah pertanian dan untuk menanggulangi keterbatasan pakan di musim kemarau.

Trichoderma $s p$ diperoleh dengan melakukan isolasi dari lahan pertanian yang kemudian ditanam pada media PDA (Potato Dextro Agar) sebagai isolat murni. Starter Trichoderma $s p$ dibuat dari biakan murni Trichoderma $s p$. untuk selanjutnya digunakan sebagai bahan fermentasi pada hijauan potensi anthelmintik.

Fermentasi Trichoderma sp dapat mempengaruhi kadar selulosa, protein, dan tanin daun potensi antelmintik secara nyata $(\mathrm{P}<0.05)$. Kadar selulosa daun potensi antelmintik turun $6.7 \%$. Kadar protein meningkat $4.81 \%$. Sedangkan kadar tanin turun $0.23 \%$.
\end{abstract}

\section{FERMENTATION EFFECTS Trichoderma sp. OF PROTEIN, TANNIN, AND CELLULOSE IN ANTELMINTIC POTENTIAL FOLIAGES}

\begin{abstract}
Efforts to increase the productivity of ruminants are usually related to two things: nutrition and health. Research on feed fermentation using microorganisms generally aims to increase nutritional value, utilize abundant agricultural waste and to overcome the limitations of food in the dry season.

Trichoderma sp was obtained by isolating from agricultural land which was then planted on PDA (Potato Dextro Agar) media as pure isolates. Starter Trichoderma sp is made from pure culture Trichoderma sp. It is used as a fermentation in the anthelmintic potential forage.

The fermentation of Trichoderma sp can affect the cellulose, protein, and tannin levels of the leaves of the antelmintic potential significantly $(P<0.05)$. The cellulose content of the anthelmintic potential decreased $6.7 \%$. Protein levels increased by $4.81 \%$. While tannin levels fell $0.23 \%$.

\section{PENDAHULUAN}

Tanaman yang memiliki kandungan tanin telah dilaporkan mampu mengurangi infestasi cacing pada ruminansia kecil. Penelitian menunjukkan bahwa tanaman jenis tanninferous dapat bernmanfaat sebagai bahan potensi pengendali kejadian infestasi nematoda pada ternak ruminansia

kecil (Akkari et al., 2008). Ahmad et al., (2012) memakai fungi nematofagus untuk mereduksi larva infektif Haemonchus contortus. Pemanfaatan daun potensi antelmintik dengan teknik fermentasi menggunakan fungi khususnya dari kelompok nematofagus, yang sekaligus
\end{abstract}


memiliki sifat dekomposer, dari jenis Trichoderma belum pernah dipublikasikan.

Tujuan penelitian adalah untuk mengetahui efek fermentasi pada hijauan daun potensi antelmintik menggunakan Trichoderma sp. Terhadap kadar protein, tannin, dan selulosa.

\section{MATERI DAN METODE}

Koleksi dan isolasi fungi Trichoderma sp.

Koleksi fungi diperoleh dengan melakukan isolasi di lahan pertanian. Isolat diperoleh dari jerami jagung yang ditumbuhi fungi. Bagian yang ditumbuhi fungi dipotong $5 \times 5 \mathrm{~mm}$ dibersihkan dengan aquades dan dibilas dua kali dengan aquades, selanjutnya fungi ditanam pada media PDA (Potato Dextro Agar) dalam cawan petri yang telah disterilkan. Miselium yang tumbuh pada media disekitar jaringan tersebut diisolasikan pada media PDA steril yang baru dalam cawan petri demikian seterusnya diulang sampai diperoleh biakan murni berupa kultur tunggal atau isolat fungi.

Isolat fungi diidentifikasi dibawah mikroskop dengan perbesaran 40 kali. Kemudian dicocokkan dengan ciri spesifiknya (Samuels et al., 2005).

\section{Pembuatan dan perbanyakan starter Trichoderma sp.}

Pembuatan starter Trichoderma $s p$ sebagai berikut. Jagung giling kasar sebagai media perbanyakan yang diperoleh dari pasar sebanyak $1 \mathrm{~kg}$ direndam dalam aquades selama 12 jam. Selanjutnya ditiriskan dan dikukus selama 10 menit. Kemudian jagung dimasukkan pada kantong tahan panas sebanyak 10 kantong selanjutnya dikukus lagi selama 1 jam. Setelah dingin setiap kantong dimasukkan biakan murni Trichoderma sp. sebanyak 1 gram. Setiap kantong diinkubasi pada suhu kamar selama satu minggu. Perbanyakan starter Trichoderma sp. yang diparoleh dikeringkan pada suhu rendah $\left(4^{\circ} \mathrm{C}\right)$ selanjutnya digunakan sebagai inokulum.

\section{Pembuatan bahan kering hijauan potensi antelmintik}

Daun yang digunakan adalah daun ketela (Manihot esculenta Crantz), daun mahoni (Swietania mahagony), daun turi (Sesbania grandoflora), dan daun nangka (Artocarpus heterophyllus) yang dikeringkan dengan dijemur.

Daun yang telah kering dipotong menggunakan mesin pemotong rumput hingga halus. Daun yang telah dipotong halus kemudian ditimbang masing-masing $5 \mathrm{~kg}$ ditempatkan pada enam kantong plastik. Sampel daun kering dimasukkan kantong plastik dan dilakukan pemeriksaan kadar protein, tanin, dan selulosa. Siap diinokulasi fungi untuk perlakuan selanjutnya.

\section{Inokulasi fungi pada bahan kering hijauan}

Kantong-kantong plastik berisi potongan hijauan daun kering disemprot dengan aquades sampai kelembaban $70 \%$, lalu ditaburkan starter fungi Trichoderma $s p$. sebanyak $10 \%$ pada masing-masing kantong plastik, kemudian tiap kantong plastik dicampur hingga merata. Campuran diinkubasi selama 8 hari. Plastik dibuka dan diambil sampel untuk dianalisa di Laboratorium.

Pengamatan dilakukan terhadap parameter pada daun potensi antelmintik. Fungi kemudian diamati viabilitas sporanya. Parameter daun antelmintik adalah kadar protein, tanin, dan selulosa. 


\section{Analisa data}

Data hasil laboratorium yang terkumpul dideskripsikan dan diuji dengan statistik untuk mengetahui pengaruh perbedaan perlakuan menggunakan student t-test nalysis (Steel dan Torrie, 1995). Data diolah dengan bantuan Microsoft excel 2007.

\section{Parameter yang diukur}

Parameter daun potensi antelmintik adalah kadar protein, tanin, dan selulosa.

\section{HASIL DAN PEMBAHASAN}

Kadar selulosa, protein, dan tanin pada daun potensi antelmintik sebelum dan sesudah fermentasi Trichoderma $s p$ disajikan dalam Tabel 1. Fermentasi Trichoderma $s p$ dapat mempengaruhi kadar selulosa, protein, dan tanin daun potensi antelmintik. Pengaruh fermentasi Trichoderma sp tersebut dianalisis menggunakan uji $t$-student menunjukkan perbedaan yang nyata $(\mathrm{P}<0.05)$.

Tabel 1. Perbedaan kadar selulosa, protein, dan tanin pada daun potensi antelmintik sebelum dan sesudah difermentasi Trichoderma sp.

\begin{tabular}{ccccc}
\hline Perlakuan & Ulangan & Selulosa & protein & Tanin \\
\hline & & & $\%$ & \\
\hline \multirow{2}{*}{$\mathrm{A}$} & 1 & 27.23 & 10.89 & 1.28 \\
& 2 & 26.90 & 11.75 & 1.29 \\
& 3 & 27.31 & 11.32 & 1.28 \\
& 4 & 27.25 & 11.70 & 1.29 \\
& 5 & 26.91 & 11.32 & 1.21 \\
$\mathrm{~B}$ & 1 & 20.73 & 16.18 & 1.06 \\
& 2 & 20.41 & 16.07 & 1.06 \\
& 3 & 20.22 & 16.13 & 1.04 \\
& 4 & 20.20 & 16.17 & 1.04 \\
& 5 & 20.20 & 16.15 & 1.04 \\
\hline
\end{tabular}

Keterangan : (A) sebelum fermentasi, (B) sesudah fermentasi.

Kadar selulosa daun potensi antelmintik turun $6.7 \%$ dari $27.15 \%$ menjadi $20.45 \%$. Kadar protein meningkat $4.81 \%$ dari $11.32 \%$ menjadi $16.13 \%$. Sedangkan kadar tanin turun $0.23 \%$ dari $1.28 \%$ menjadi $1.05 \%$.

Peningkatan kadar protein, seperti juga yang telah diteliti Supriyati (2010) disebabkan karena dalam proses fermentasi ditambahkan sumber $\mathrm{N}$ yang berupa tepung jagung. Trichoderma memanfaatkan N untuk membentuk protein. Peningkatan juga disebabkan adanya kenaikkan massa sel Trichoderma sp. dengan pembentukan miselium (Harman et al., 2004).

Tanin memiliki kemampuan antiparasit karena menghambat enzim dan merusak membran sel, bersifat ovisidal, serta mengendapakan protein (Molan et al., 2000). Berkurangnya kadar tanin dalam tanaman karena pemanasan atau lainnya mengakibatkan berkurang pula kemampuan antelmintiknya (Makkar, 1999). Fermentasi Trichoderma pada daun potensi antelmintik mengurangi kadar tanin dari $1.28 \%$ menjadi $1,06 \%$.

Produk fermentasi biasanya mempunyai nilai nutrisi yang lebih tinggi dari pada bahan aslinya karena adanya enzim yang dihasilkan dari mikroba itu sendiri (Winarno dan Fardiaz, 1989). Beauchemin et al.,(2003) menyatakan bahwa mikrobia selulolitik pada umumnya akan mensekresikan tiga jenis enzim, yaitu: 
endoglukanase atau carboxymethylcellulase (CMC-ase), eksoglukanase, dan $\beta$ glukosidase. Secara sinergis ketiga jenis enzim ini mendegradasi selulosa menjadi glukosa. Miselium Trichoderma dapat menghasilkan suatu enzim yang bermacammacam, termasuk enzim selulase. Fermentasi Trichoderma mampu menurunkan kadar selulosa 27,23\% menjadi $20,22 \%$.

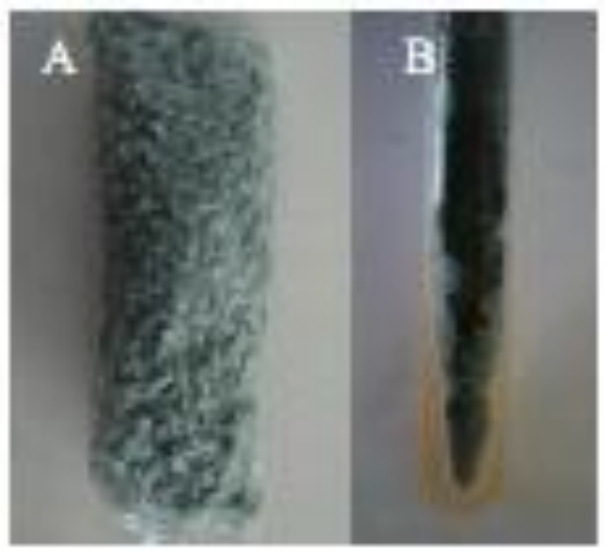

Gambar 1. (A) Trichoderma sp pada media beras, (B) Trichoderma $s p$ pada media PDA.

\section{KESIMPULAN}

Fermentasi fungi nematofagus Trichoderma sp. meningkatkan secara signifikan kadar protein namun menurunkan kadar tanin dan selulosa hijauan daun potensi antelmintik.

\section{SARAN}

Perlu penelitian In vitro lebih dalam untuk mengetahui interaksi fungi nematofagus Trichoderma $s p$ dan daun potensi anthelmintik.

\section{DAFTAR PUSTAKA}

Ahmad, RZ., F Satrija, N Sukarno, dan FH Pasaribu. 2012. Pemakaian Duddingtonia flagrans dan
Saccharomycer cerevisiae dalam Mereduksi Larva Infektif Haemonchus contortus. Jurnal Veteriner Vol.13 No.I: 70-76.

Akkari, H., M.A. Darghouth, and H.B. Salem. 2008. Preliminary Investigations of The antinematode Activity of Acacia cyanophylla Lindl:: Excretion Gastrointestinal Nematode Eggs in Lambs Browsing A. cyanophylla With and Without PEG or Grazing Native Grass. $J$. Small Rum Res. 74: 78-83.

Beauchemin, K. A., D. Colombatto, D. P. Morgavi. And W. Z. Yang. 2003. Use of exogenous fibrolytic enzymes to improve feed utilization byruminant. J Anim. Sci.

(E.Suppl. 2) : E 37 - E 47

Harman. G. E., C. R. Howel., A. Viterbo., I. Chet., and M. Lorito. 2004. Trichoderma spesies Opportunistic, Avirulent Plant Symbionts. Nature Review Microbiology Volume 2.www.nature.com. Diakses tanggal 20 Januari 2014.

Makkar, H.P.S. 1999. Role of tannins and saponin in nutrition. In Proceeding of The Seventh Scientific Workshop in Tromso : Effects of Antinutritional Value of Legume Diets.

Molan, A. L., G. C. Waghorn, B. R. Min, and W. C. McNabb. 2000. The effect of condensed tanin from seven herbages on Trichostrongylus colubriformis larval migration in vitro. Folia Parasitol. 47:39-44.

Samuels, GJ. 2005. Trichoderma: Systematics, the Sexual State, and Ecology. Symposium The Nature 
and Application of Biocontrol

Microbes II: Trichoderma spp. Vol.

96, No. 2, 2006195.

Steel RGD dan JH Torrie. 1995. Principles and Procedures of Statistic. Edisi Bahasa Indonesia. Gramedia Pustaka Utama, Jakarta.

Supriyati, T. Haryati, I-G.M. Budiarsana dan I-K. Sutama. 2010. Fermentasi Jerami Padi Menggunakan Trichoderma viride. Seminar Nasional Teknologi Peternakan dan Veteriner 2010. Bogor.

Winarno, F. G. dan S. Fardiaz.1989. Mikrobiologi Pangan. Departemen Pendidikan dan Kebudayaan Direktorat Jenderal Pendidikan Tinggi PAU Pangan dan Gizi IPB. 